Copyright (C) 2017 by Academic Publishing House Researcher

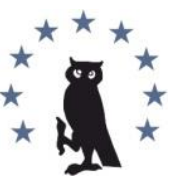

Published in the Russian Federation

European Researcher. Series A

Has been issued since 2010.

ISSN 2219-8229

E-ISSN 2224-0136

2017, 8(2): 98-103

DOI: 10.13187/er.2017.2.98

www.erjournal.ru

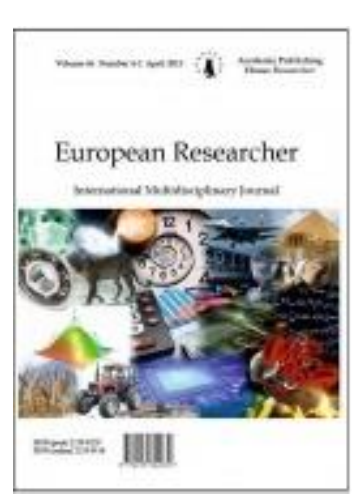

UDC 33

\title{
Prospects of Cooperation between Russia and Turkey
}

\author{
Elvin Aghayev a , * , Hayati Aktaş ${ }^{\mathrm{b}}$ \\ a Istanbul Aydin University, Turkey \\ b Antalya AKEV University, Turkey
}

\begin{abstract}
Russian - Turkish relations go deep into the past. From the Cold War and the relations between the Soviet Union and the United States certainly there has not been a more complicated relationship in international relations. Both countries have different strategic positions, a different dominant religion, a different past, but their relationship largely depends on the future of Eurasia. This paper will deal with relations between the two countries since the establishment of the first diplomatic contacts in the 15th century, through the relationship during the time of Peter the Great, and will mention the periods of the First and Second World Wars, as well as the Cold War era. Special attention will be focused on the current relations between the two countries, especially after the conflict in 2015, when Turkey shot down a Russian plane over Syria. Special attention will be focused on energy policy and the potential for building a nuclear power plant in Mersin, and the continuation of Turkish stream. The paper will deal with economics and trade exchange, which have almost disappeared following the 2015 incident, security cooperation and Turkey's plans to buy the defense system S-40o from Russia, as well as relations between the two countries towards NATO. The paper will end with the projection of the prospects for the economic relations between the two countries.
\end{abstract}

Keywords: Russia, Turkey, Akkuyu, Turkish Stream, Eurasia.

\section{Introduction}

In modern international relations, there is probably no more complex relationship than the one between Russia and Turkey. Both countries are found in the concepts of Eurasianism, multipolarity, authoritarianism, and technical modernity. Both countries have calculated that their mutual cooperation can bring substantial benefits in the post-Cold War period and that a lot of time has to pass before the geopolitical imperatives force them to shoot down arms in a direct trial of strength. In the case of an open escalation, they are aware that they can put each other into some kind of stalemate, but that neither one can take a direct win.

The history of relations between Russia and Turkey contains many impressive sites and unexpected turns. Historians calculate that these two countries have fought each other ten times. Some of these wars can only conditionally be characterized as the Russian-Turkish (for example, march of Peter the First on the river Prut), but there is no doubt that the Turks were opposed to

\footnotetext{
${ }^{*}$ Corresponding author

E-mail addresses: elvinagayev@stu.aydin.edu.tr (E. Aghayev), h.aktas@akev.edu.tr (H. Aktaş)
} 
Russia on the battlefield far more than other nations. Most of these wars ended with Russia's victory, expanding its territory, and strengthening its influence, particularly among the nations of South East Europe that were under Turkish Ottoman rule.

The first diplomatic act in the history of Russian-Turkish relations is the letter of the Russian prince Ivan III to Ottoman Sultan Bayezid II, sent in 1492 (İnalcık, 1994). In this document, the Russian prince writes about the most important issues of development of the sea trade between Moscow and Constantinople in the waters of the Black and Azov Sea. This letter justified tradeeconomic cooperation between the two countries. On the political and diplomatic field, RussianTurkish relations were formally established by Peter I in 1701 with the opening of the Russian embassy in Constantinople. That made it possible for the two countries to have a channel for mutual political action.

In the First World War, the Russian-Turkish front was not a priority. In the Caucasus, Russian troops failed to take Erzurum, Trabzon, and Bitlis. During the Persian campaign 19141916, the Russian army repressed Turkish troops from Persia. However, the revolution in Russia actually led to the termination of military operations.

The Turkish Republic declared in 1923 was deliberately formed as an antithesis to the Ottoman Empire, which collapsed defeated in the World War I. The new leader of Turkey, Mustafa Kemal, designed a radically new type of state, including the political system, legal framework, social, political, and government institutions. Mustafa Kemal was an ally of the founder of the Soviet Union - Lenin. As in the case of Weimar Germany, this was a temporary alliance of two internationally isolated countries. For Turkey, military and financial aid from the Bolsheviks, as well as approval of the military strategy by Moscow, was important to defeat the Greek intervention, which was actively supported by the Entente countries, especially by England. Turkey was very important for Soviet Russia in the confrontation with Entente.

The Soviet Union not only provided military support to Turkey, but also, in 1921, Moscow appointed Mikhail Frunze, one of the most gifted Soviet military leaders, as a military adviser in Ankara. Apart from weapons and gold, the Bolsheviks provided Turkey with food products despite famine in the Soviet Union. It is not accidental that today in the central part of Istanbul, on the Taksim Square the Republic Monument is situated, where the Russian generals Kliment Voroshilov and Semen Aralov are centered in the Ataturk sculpture.

In World War II, Turkey was neutral, but in 1952, they joined NATO. This, however, did not negatively affect the Soviet-Turkish relations. In May 1953, the authorities of the Soviet Union published a statement that "the Government of Armenia and Georgia believe they can give up its territorial claims against Turkey". At the same time, "Soviet power considers that it can ensure the safety of the Soviet Union from the direction of the strait, under conditions that are equally acceptable for both the SSSR and for Turkey" (Geoffrey, 2011). We should bear in mind that the decision of US President John F. Kennedy in 1961 to deploy American medium-range missiles in Turkey caused a response from the Soviet Union in the form of the deployment of Soviet missiles in Cuba, and thus caused the Caribbean crisis (Scott, Hughes, 2015).

As for the modern era, the relations are very turbulent. In the paper, we will pay special attention to some of the most important segments of cooperation between the Russian Federation and Turkey.

\section{Discussion and Results}

\subsection{Cooperation in Energy Sphere}

In satisfying the major part of its needs for energy, Turkey depends largely on imports from abroad. Over the past fifty years, the attempts to develop nuclear power plant projects have failed. Like any other great power, Turkey would be a leader in the region if it found a radical solution to its energy problems. Turkey believes that nuclear stations represent a very useful means to obtain energy.

Today, Russia and Turkey have opened a new page in their bilateral relations. On the 12th of May 2010, the Russian and Turkish governments signed a treaty in Ankara for the construction of a nuclear power plant Akkuyu in the Mersin province. A nuclear power plant in the Turkish province of Mersin on the Mediterranean coast is being built by the company Rosatom (Russian State Atomic Energy Corporation). The plant will have four blocks of 1,200 MW, and according to the plan the release of the first block will be in six years. In 2019, the first generating set will be 
constructed, with the other three sets being constructed at intervals. The Akkuyu nuclear power plant with operational power of $4,800 \mathrm{MW}$ will cover the energy deficiency in Turkey to a significant extent. The life cycle of the nuclear plant is rated for 60 years. Total cost of the power plant as designed is around 20 billion dollars (World Nuclear Association, 2017). Pursuant to the bilateral treaty, the Russian party will defray all the construction expenses, and later, the nuclear power plant will be beneficially owned by Russia, not subject to transfer to the Turkish party. Also, according to mass media reports, to date, the Russian party has spent about 3 billion dollars towards this large-scale project.

Furthermore, the Russian party has started training about 120 Turkish employees to work on the Akkuyu project. The project has proposed increasing this figure up to 600 students.

There were some objections on the part of the Turkish community and of Mersin citizens to the construction of this nuclear power station, but in 2012, the design contractor Atomstroyexport opened an information center to raise awareness to the local community.

Ankara is intent upon increasing the number of nuclear power stations in the country. The next one is to be constructed will be in Sinop city and be constructed by the Japanese and French. Turkish students who have studied in Russia will play a significant role in the project management.

Energy partnership between Russia and Turkey goes far beyond negotiations on major projects such as gas lines to the Western Europe. In the energy sector, relationships between these two countries will intensify in different areas to meet the economic ambitions of both countries. Russia is very interested in building a gas pipeline referred to as "Turkish Stream". Energy ministers of Russia and Turkey signed an agreement for the construction of this gas pipeline as of October 2016 in Istanbul. The proposed pipeline will carry gas from Russia to Turkey, and from there it will be distributed to member countries of the European Union. The project envisages the construction of a gas pipeline across the Black Sea to the European part of Turkey's territory with subsequent extension to the border with Greece. The length of the gas pipeline across the Black Sea will be 910 kilometers and 180 kilometers via Turkey. The project value is estimated at 11.4 billion euros (Gazprom plans..., 2017). In early May 2017, the construction began. The work of laying the pipes began with the Russian Black Sea coast. The project was suspended due to tensions caused by the Turkish folding the Russian aircraft in November 2014, and negotiations continued through last year after bilateral relations improved. Construction of this pipeline is vitally important to both countries. It would support their common interest, it would position them on the world market, but it would also bring great financial benefit.

Although there are some differences between political interests, for example, in respect of the Middle East, which indicates only partial agreement between the countries primarily based on energy issues, these differences have no negative influence on the close economic dialogue between Russia and Turkey aimed at implementation of the integrated power strategies of either country.

Modern Russia is interested in the development of an energy partnership with the Turkish Republic. Economic cooperation between the countries in this area will promote detailed study and successful implementation of future joint projects.

\subsection{Development of Military Cooperation}

Relations between the Russian Federation and Turkey are being spread over different levels. One of them is the military cooperation. In the first half of 2017, there were talks between Russian and Turkish officials on the sale of the powerful Russian defense system S-400 to Turkey. S-400 Triumph is the anti-missile defense system capable of intercepting all types of modern aircraft weapons, including a fifth-generation aircraft and ballistic and cruise missiles to a maximum range of almost 250 kilometers. The complex, which consists of up to eight battalions, officially can be engaged to 80 targets. S-400 is equipped with four different types of projectiles, including those of a very long range $40 \mathrm{~N} 6$, which have an operating range of up to $400 \mathrm{~km}$. It also has long-range missiles 48N6 $(250 \mathrm{~km})$, medium-range 9M96E2 $(120 \mathrm{~km})$, and short-range 9M96E (40 km) (Turkey and Russia..., 2017). The future of the project depends on several factors. The first is financing, the Russian side was explicit when it comes to that and they maintained the attitude that they would not sign a contract of sale until the loan contract is signed. Then, another problem is the use of weapons, the Russians are afraid that the defense system will be used in the context of NATO, while Turkey, a member of the military alliance, claims that it will not happen. Turkey also 
has not talked about how it intends to get out of this military alliance or to deny hospitality to their military bases.

The relations between Russia and Turkey significantly deteriorated following the overthrow of the Russian Sukhoi. At the beginning of 2017, relations appear to be progressing on all fields, but it does not exclude the progress of military and military/technical cooperation. Turkish officials have repeatedly declared that NATO allies are not interested in the view of sharing technologies and also about the issue of investment in the Turkish defense industry. In addition, potential defense cooperation between the Russian Federation and Turkey could be based on the common fight against terrorism or sharing information and preventing terrorist attacks in both countries. Certainly, the most significant step was the announcement of Turkish officials about buying defense system S-400. However, in 2013, Turkey announced a tender for setting up a defense system within its territory (Kasapoglu, 2017). In the competition of the American Patriot system and the French-Italian consortium, which offered SAMP / T Aster 30 Block-1, the Chinese won, but NATO revolted against it, and that job did not succeed. Potential purchase of S-40o, would certainly mean a cooling down of relations between Turkey and NATO, but also could mean significantly better relations between the Russian Federation and Turkey.

\subsection{Prospects of Economic Relations}

In the context of globalization, the modern world has changed drastically, with economies being much more interdependent than, say, one hundred years ago. While the problem of coordination of national and global interests, including economic ones, is more relevant than ever, it is important to note that today economic cooperation plays an important role in the Russian and Turkish relations. It depends to a certain extent on the will of the leaders of both countries.

Russia and Turkey have a huge trade exchange. It was, of course, slowed down during the recent disagreements between these two entities, but it is slowly returning to normal. In recent years, it has increased. Due to sanctions imposed on Russia, almost all produce is being provided to Russia by Turkey. However, for some fruits and vegetables there is still a ban on imports. And although the relations are better, there are still some obstacles. If we take for example a tomato, this product is on a "black list" and it is not imported from Turkey. Therefore, Morocco exports tomatoes to Russia. Almost $60 \%$ of the total quantity of tomatoes in Russia are coming from Morocco (Arbaoui, 2015). As for oranges and citrus fruits, they are mainly coming from Egypt to the Russian Federation. After the problems between Russia and Turkey, Egypt jumped in to take up the space in the market. Not only because of the deterioration of relations between the two countries, but also because of geographical inaccessibility of the terrain for the growth of these crops in Russia. Since 2015, about 25 \% of total production of citrus fruit from Egypt go to Russia, or more than 500,000 tons. If Russia and Turkey want to raise mutual value of trade to 100 billion, these are some of the things around which they definitely need to negotiate.

Tourism is one of many industries that underpins the relations between Russia and Turkey. Turkey became the first country to send visitors to the former Soviet Union on vacation. Great service, affordable prices, resorts for all tastes, and, above all, no need for visas, have always attracted the Russian tourist flow to the Turkish seacoast. Besides, in recent years, the first Russian tourists have visited Turkey's ski resorts. Thus, Turkey has turned into a year-round tourist paradise for people from the CIS.

Also, it can be said that tourism in Turkey has lost major clients after the overthrow of the Russian aircraft SU-24. Following the overthrow of the aircraft and the initiation of sanctions on Ankara, the number of Russian tourists declined by almost 30 times, which is a disaster for the Turkish economy. Since the warming of relations between the two countries, Turkish restaurateurs are hoping for the arrival of millions of Russians to their country. It is expected that 4.5-5 million people will arrive. That is really impressive number compared to the 800,000 visitors in 2016 (Turkish tourism..., 2016).

The knockdown of Russian aircraft over the skies of Syria has threatened the construction industry on the Ankara - Moscow route. After the fall of the Soviet Union, an important place in the market of construction companies in Russia is occupied by the Turkish companies. Turkish construction companies, including giants such as the company "Enka", participate in infrastructure construction across Russia. Two large towers in business-residential complex "Moscow City", Tower East and Tower Evolution, are the work of the Turkish builders, and also a large part of the 
infrastructure for the World Cup. According to some estimates, Turkish companies made the agreements at a rate of one to two and a half billion dollars, but they have built millions of square meters of residential and office space in Moscow alone. Turkish construction companies have thus become key players in this market. It is estimated that in the last few decades, Turkish companies have concluded contracts worth 50 billion dollars and that they have built about 24 million square meters only in Moscow. In 2016, Russia began with the overthrow of quotas for Turkish builders with around 100,000 as were legally registered, to just over 50,000. The warming of relations will mean the return of Turkish builders to the Russian market (Sharkov, 2016).

One of the most important goals of cooperation between these countries consists in trade exchange using their national currencies. The Turkish party repeatedly expressed their wish to pursue this goal. For example, in the first half of the previous year, Turkey exported goods for Russian rubles, which amounted to 62 million 547 thousand dollars (Ferhan, Dalkınıç 2016). Year by year, the parties are planning to increase the amount of national currencies involved in their trade exchange, which has become one of the overarching priorities in cooperation between Russia and Turkey.

This is a very important issue in relations between the two countries. Monetary independence could greatly contribute to relations between Russia and Turkey, it would not only bring the two countries closer, but it would also strengthen the region. On the other hand, it would not have encountered the justification of monetary powerful countries, primarily referring to the US and the European Union. The initiative of cooperation between the two currencies is not recent, it dates from 2015. At that time, the joint Russian-Turkish business council meeting discussed how the big projects could be paid in local currency - the lira and ruble. There were even some saying that Russian tourists in Turkey could use ruble, rather than dollars or euros or to change foreign currency in the local exchange offices. This initiative stopped after the overthrow of the Russian aircraft and plans to continue this initiative have yet to come to fruition.

In early August of the last year, Saint Petersburg held a bilateral summit where the parties agreed on a medium-term program, which will continue until 2019. The leaders of the countries made the important decision to increase their trade from 35 to 100 billion dollars (Berber, 2013). However, where cooperation in certain areas determines overall economy, the governments may attach little importance to some crisis phenomena. Continuing energy cooperation between Russia and Turkey in crisis provides a striking example to this; gas supplies to the Turkish party exceeded those of the pre-crisis period by 1 billion dollars. Neither party preferred to stop the gas supply, realizing that both economies would suffer.

\section{Conclusion}

Russia and Turkey have very close and longstanding bonds of history, economy, culture, and social heritage. Even during the Cold War, though taking opposing positions, the countries found a variety of methods to cooperate within the same geography.

Participation in a variety of large-scale energy projects on a regional level enables Turkey to have more voice during negotiations with Russia by successfully developing the strategy of an energy hub; however, they bear the risk of a growing dependence on Russia. Negotiations with Turkey and other members of the energy market enable Russia to respond quickly to European diversification projects.

In the context of consolidation of the role of the energy factor in the international policy, cooperation in the fuel and energy sector, undoubtedly, has determined the trajectory of the Russian-Turkish relations over the years. It is quite natural that Russia and Turkey continue cooperation in this area of strategic significance for both countries. An independent background is available for such cooperation, since one of these countries holds vast reserves of energy and welldeveloped fuel and energy infrastructure, while the other feels an increasing need for sources of energy for the rapidly developing economy and improves its energy capacity, including by using advantageous geographical location to carry energy resources across its territory.

Turkish overthrow of the Russian aircraft represents the worst escalation of an already explosive situation. Turkey does not want to give up its plans in northern Syria nor can Russia afford the luxury of turning a blind eye to a thrown glove. Further development of this crisis will depend mostly on two factors. The first is whether Russia and Turkey can formulate a protocol on 
actions in northern Syria, which would prevent contamination of overall relations, by which the both sides would lose. The second is, of course, the US position.

The leaders of the countries, first of all, must carefully assess every step on the international arena, evading quick-fix adventurous decisions, and take into consideration any economic losses that could result from further military engagement.

\section{References}

İnalcık, 1994 - Inalckk, Halil (1994). An Economic and Social History of the Ottoman Empire Volume I (1300-1600). UK: Cambridge University Press, pp. 278-279.

Geoffrey, 2011 - Roberts, Geoffrey (2011). Molotov: Stalin's Cold Warrior. Potomac Books. pp. 107-108.

Scott, Hughes, 2015 - Scott, Len; R. Hughes, Gerald (2015). The Cuban Missile Crisis: A Critical Reappraisal. Taylor \& Francis. p. 17.

World Nuclear Association, 2017 - World Nuclear Association (2017). Nuclear Power in Turkey. [Electronic resourse]. URL: http://www.world-nuclear.org/information-library/countryprofiles/countries-t-z/turkey.aspx Retrieved 10 March 2017

Gazprom plans..., 2017 - Gazprom plans to begin laying Turkish Stream in summer (2017). ITAR-TASS. [Electronic resourse]. URL: http://tass.com/economy/943604 Retrieved 29 April 2017.

Turkey and Russia..., 2017 - Turkey and Russia cosy up over missiles (2017). The Economist. [Electronic resourse]. URL: http://www.economist.com/news/europe/21721665-their-friendshipshould-worry-nato-turkey-and-russia-cosy-up-over-missiles Retrieved 8 May 2017

Kasapoglu, 2017 - Kasapoglu, Can (2017). Why Turkey might buy Russia's S-40o defence system. Al Jazeera. [Electronic resourse]. URL: http://www.aljazeera.com/indepth/opinion /2017/o3/turkey-buy-russia-s400-missile-defence-system-170323131537509.html Retrieved 15 May 2017

Arbaoui, 2015 - Arbaoui, Larbi (2015). Russia Eyes Moroccan Tomatoes, Citrus After Crises with Turkey, Morocco World News, [Electronic resourse]. URL: https://www.moroccoworldnews. com/2015/11/173688/russia-eyes-moroccan-tomatoes-citrus-after-crises-with-turkey/ Retrieved 17 May 2017

Turkish tourism..., 2016 - Turkish tourism representative expects 3 million Russian tourists in 2017 (2016). Hurriyet Daily News. [Electronic resourse]. URL: http://www.hurriyetdailynews. com/turkish-tourism-representative-expects-3-million-russian-tourists-in-2017-.aspx?page $=238 \& n I D=107481 \&$ NewsCatID=349 Retrieved 19 May 2017.

Sharkov, 2016 - Sharkov, Damien (2016). Putin Says Russia Will Extend Sanctions on Turkish Firms, Newsweek, [Electronic resourse]. URL: http://www.newsweek.com/russias-putinsanctions-turkey-extended-419679 Retrieved 22 May 2017

Ferhan, Dalkınıç 2016 - Ferhan, E. Yeşilyurt; Dalkınıç Sümeyye (2016). İhracatçllar da Rusya ile ticarette lira ve ruble kullanmak istiyor, Anadolu Ajansı [Electronic resourse]. URL: http://aa.com.tr/tr/ekonomi/ihracatcilar-da-rusya-ile-ticarette-lira-ve-ruble-kullanmak-istiyor /627319 Retrieved 24 May 2017

Berber, 2013 - Berber, A. Mehmet (2013). Turkey and Russia set trade volume target of $\$ 100$ billion in 2020, Daily Sabah [Electronic resourse]. URL: https://www.dailysabah.com/business /2013/11/23/turkey-and-russia-set-trade-volume-target-of-10o-billion-in-2020 Retrieved 25 May 2017. 